\title{
Effect of Different Inducers on the Essential Oil of Suspension Culture Cells from Cinnamomum longepaniculatum
}

\author{
Linman He, Kuan Yan*, Mingbo Xiao \\ College of Sichuan Tea, Yibin University, Yibin, China \\ Email: *158542439@qq.com
}

How to cite this paper: He, L.M., Yan, K. and Xiao, M.B. (2019) Effect of Different Inducers on the Essential Oil of Suspension Culture Cells from Cinnamomum longepaniculatum. Open Access Library Journal, 6: e5803. https://doi.org/10.4236/oalib.1105803

Received: September 19, 2019

Accepted: October 12, 2019

Published: October 15, 2019

Copyright $\odot 2019$ by author(s) and Open Access Library Inc.

This work is licensed under the Creative Commons Attribution International License (CC BY 4.0).

http://creativecommons.org/licenses/by/4.0/

\begin{abstract}
In this study, the effects of different inducers on the accumulation of essential oil (1,8-eucalyptus) in suspension cells of Cinnamomum longepaniculatum were studied by adding different inducers, and the differences in the effects of different inducers on the yield and quality of essential oil in suspension cells of $C$. longepaniculatum were revealed. The results showed that under the same conditions, the addition of $\mathrm{CaSO}_{4} 1.5 \mathrm{mg} / \mathrm{L}, \mathrm{Li}_{2} \mathrm{SO}_{4} 1.0 \mathrm{mg} / \mathrm{L}, \mathrm{SA} 15$ $\mathrm{mg} / \mathrm{L}$ and $\mathrm{H}_{2} \mathrm{O}_{2} 9 \mathrm{mmol} / \mathrm{L}$ in $\mathrm{B} 5$ medium could significantly promote the accumulation of essential oil, which was $60.94 \%, 54.69 \%$, 36.72\% and $35.16 \%$ higher than that of CK, reaching $0.0824 \mathrm{mg} / \mathrm{L}, 0.0792 \mathrm{mg} / \mathrm{L}, 0.0700 \mathrm{mg} / \mathrm{L}$ and $0.0692 \mathrm{mg} / \mathrm{L}$, respectively. Through orthogonal test, it was found that 2.0 $\mathrm{mg} / \mathrm{L} \mathrm{CaSO}_{4}$ combined with, $\mathrm{H}_{2} \mathrm{O}_{2} 9 \mathrm{mmol} / \mathrm{L}$, SA $15 \mathrm{mg} / \mathrm{L}$ and $\mathrm{Li}_{2} \mathrm{SO}_{4} 0.5 \mathrm{mg}$ $/ \mathrm{L}$ presented significant differences compared with other combinations $(\mathrm{P}<$ 0.05 ), and the yield reached $0.1768 \mathrm{mg} / \mathrm{L}$, which increased by $245.31 \%$. The experiment showed that the addition of inducer was an effective way to promote the accumulation of essential oil in suspension cells, and provided a reference for the manual regulation and strengthening of metabolism synthesis in this lifetime of suspension cells.
\end{abstract}

\section{Subject Areas}

Biochemistry, Biotechnology

\section{Keywords}

Cinnamomum longepaniculatum, Suspension Cells, Single Factor Orthogonal Test

\section{Introduction}

Cinnamomum longepaniculatum (Gamble) N. Chao is an evergreen tree of the 
genus Cinnamomum of the family Lauraceae. C. longepaniculatum is a precious tree species in the genus Aphididae. The distribution is mainly concentrated in Taiwan, China and Yibin, Sichuan. The oil of C. longepaniculatum can be extracted from the leaves, stems and roots of $C$. longepaniculatum by steam distillation. At this stage, the oil extracted from C. longepaniculatum in Yibin is mainly essential oil [1].

The essential oil of $C$. longepaniculatum is mainly composed of dozens of different chemicals [2], and the main component 1,8-eucalyptus [3] is widely used in many industries, such as spices, food, medicine, chemical and defense. With the increase of the world's population and the improvement of people's material living standards, the demand for medicines, foods, spices, etc. has increased, and the demand for 1,8-eucalyptus has increased rapidly [4] [5] [6] [7].

Suspension cell culture refers to establish callus or excised plant cells and transfers to a liquid medium for sterile shaking culture [8]. The relatively uniform cells obtained by this culture method not only provide a unique experimental system for studying cell proliferation and differentiation, but also have a rapid cell proliferation rate and are suitable for large-scale culture. Therefore, there is a huge application potential in the industrial production of plant products [9] [10].

With the rapid development of society and the continuous improvement of people's quality of life, the demand for natural flavors such as essential oil has doubled, leading to a growing contradiction between supply and demand. Coupled with the plant's secondary metabolite instability and environmental constraints, the yield and quality of the essential oil cannot meet the demand. Therefore, the study of the influencing factors of essential oil is of great significance for significantly increasing the yield of essential oil, and has become an important content and a new development direction of $C$. longepaniculatum resources and plant aromatic oil research.

In the process of suspension culture of plant cells, the activity of enzymes in cell metabolism can be activated by adding exogenous inducers [11], thus increasing the production of secondary metabolites in oil suspension cells, and sometimes even inducing the new production of secondary metabolites in oil suspension cells [12] [13], with the continuous development of plant tissue and cell culture technology, cell suspension culture system is becoming more and more perfect. It has always been a hot spot for researchers to study how to use plant cell suspension culture technology to produce useful secondary metabolites and increase metabolite production [14] [15]. This technique of using elicitors to increase the production of secondary metabolites in oil suspension cells in the short term is currently a more mature method [16]. Therefore, finding suitable inducers can effectively increase the secondary metabolites of suspended cells and improve the oil production rate, which has high research value and application prospects.

\section{Materials and Methods}

\section{Materials}


All young leaves were sourced from the $C$. longepaniculatum base of Hongyan Mountain in Yibin. Cut the leaves blade into the appropriate size (should be placed in a sterile container) and rinse with running water for a few minutes to 30 minutes. Then soaked in $70 \%$ alcohol for 10 to 30 seconds and washed it 3 to 10 times with sterile water. Inoculated the treated aseptic explants in a $100 \mathrm{ml}$ solid triangular medium.

\section{Main Drugs and Medium}

Inducers: $\mathrm{CuSO}_{4}, \mathrm{FeSO}_{4}, \mathrm{Li}_{2} \mathrm{SO}_{4}, \mathrm{MnSO}_{4}, \mathrm{CaSO}_{4}, \mathrm{H}_{2} \mathrm{O}_{2}$, tryptophan, SA (salicylic acid), sodium benzoate $\mathrm{B} 5$ medium: A large number of elements 1: $\mathrm{KNO}_{3}$ $50 \mathrm{~g}, 1 \mathrm{~L}$ (take $50 \mathrm{ml}$ ); A large number of elements 2: $\mathrm{CaCl}_{2}-2 \mathrm{H}_{2} \mathrm{O} 3 \mathrm{~g}$, $\mathrm{MgSO}_{4}-7 \mathrm{H}_{2} \mathrm{O} 5 \mathrm{~g},\left(\mathrm{NH}_{4}\right)_{2} \mathrm{SO}_{4} 2.68 \mathrm{~g}, \mathrm{NaH}_{2} \mathrm{PO}_{4}-2 \mathrm{H}_{2} \mathrm{O} 3 \mathrm{~g}$, $1 \mathrm{~L}$ (take $50 \mathrm{ml}$ ); Trace element 1: $\mathrm{KI} 75 \mathrm{mg}, \mathrm{H}_{3} \mathrm{BO}_{3} 300 \mathrm{mg}, \mathrm{MnSO}_{4}-\mathrm{H}_{2} \mathrm{O} 1000 \mathrm{mg}, \mathrm{ZnSO}_{4}-7 \mathrm{H}_{2} \mathrm{O} 200$ mg, $\mathrm{Na}_{2} \mathrm{MoO}_{4}-2 \mathrm{H}_{2} \mathrm{O} 25 \mathrm{mg}, 500 \mathrm{ml}$ (take $5 \mathrm{ml}$ ); Trace element 2: $\mathrm{CuSO}_{4}-5 \mathrm{H}_{2} \mathrm{O}$ $25 \mathrm{mg}$, CoCl- $6 \mathrm{H}_{2} \mathrm{O} 25 \mathrm{mg}, 500 \mathrm{ml}$ (take $0.5 \mathrm{ml}$ ); Iron salt: $\mathrm{FeSO}_{4}-7 \mathrm{H}_{2} \mathrm{O} 2780 \mathrm{mg}$, $\mathrm{Na}_{2}$-EDTA-2 $\mathrm{H}_{2} \mathrm{O} 3730 \mathrm{mg}, 500 \mathrm{ml}$ (take $5 \mathrm{ml}$ ); Organic matter: Inositol 10,000 $\mathrm{mg}$, niacin $100 \mathrm{mg}$, Pyridyl hydrochloride $100 \mathrm{mg}$, Thiamine hydrochloride 1000 $\mathrm{mg}$, $500 \mathrm{ml}$ (take $5 \mathrm{ml}$ ).

\section{Test Design}

B5 medium was used as the basic medium, and the single factor test of different levels of the same inorganic inducer was set up (Table 1), the single factor test of different levels of the same organic inducer (Table 2) and different inducers. Orthogonal test (Table 5), the medium was dispensed into a $150 \mathrm{~mL} \mathrm{Er}$ lenmeyer flask, repeated for 3 bottles treatment, and sterilized at $115^{\circ} \mathrm{C}$ for 20 min in an autoclave. After cooling, callus solid cells were transferred to liquid medium. The callus solid cells were cultured for 28 days in $25^{\circ} \mathrm{C}$ in a constant temperature incubator, and its essential oil production was measured every 7 days during its cultivation.

Table 1. Single factor test of inorganic inducer.

\begin{tabular}{ccccc}
\hline Inorganic inducer & \multicolumn{5}{c}{ Level } \\
\hline $\mathrm{CuSO}_{4}(\mathrm{mmol} / \mathrm{L})$ & 0.01 & 0.02 & 0.03 & 0.04 \\
$\mathrm{FeSO}_{4}(\mathrm{mmol} / \mathrm{L})$ & 0.02 & 0.035 & 0.05 & 0.075 \\
$\mathrm{Li}_{2} \mathrm{SO}_{4}(\mathrm{mg} / \mathrm{L})$ & 0.5 & 1 & 1.5 & 2 \\
$\mathrm{MnSO}_{4}(\mathrm{mmol} / \mathrm{L})$ & 1 & 3 & 5 & 7 \\
$\mathrm{CaSO}_{4}(\mathrm{mg} / \mathrm{L})$ & 0.05 & 0.1 & 0.15 & 0.2 \\
$\mathrm{H}_{2} \mathrm{O}_{2}(\mathrm{mmol} / \mathrm{L})$ & 3 & 6 & 9 & 12
\end{tabular}

Table 2. Single factor test of organic inducer.

\begin{tabular}{ccccc}
\hline Inducer & \multicolumn{5}{c}{ Level } \\
\hline Tryptophan $(\mathrm{g} / \mathrm{L})$ & 0.14 & 0.144 & 0.148 & 0.152 \\
SA (mg/L) & 5 & 15 & 25 & 35 \\
Sodium benzoate $(\mathrm{mg} / \mathrm{L})$ & 5 & 10 & 15 & 20 \\
\hline
\end{tabular}




\section{Methods \\ Cultivation of suspension cells and establishment of suspension sys-} tem

The inoculated explants were placed in a culture chamber, and the temperature was controlled at about $23^{\circ} \mathrm{C}$. After the callus induction was completed, it was subcultured twice. The transfer was performed twice, and about $2.0 \mathrm{~g}$ of the well-grown and loose pink callus was inoculated into a $150 \mathrm{~mL}$ Erlenmeyer flask containing $50 \mathrm{~mL}$ of B5 medium at a speed of $110 \mathrm{r} / \mathrm{min}$ at $25^{\circ} \mathrm{C}$. Shake culture under shading conditions. 14 days were subcultured once, followed by 2 times.

\section{Inducer Single Factor Test}

B5 medium was prepared, and the inorganic inducer was added to the same amount of inducer after each component, and sterilized at $115^{\circ} \mathrm{C}$ for $20 \mathrm{~min}$ in an autoclave with an inoculation needle; organic inducer for sterilization in a high-pressure steam sterilization pot at $115^{\circ} \mathrm{C}$ for $20 \mathrm{~min}$, after cooling, an equal amount of each organic concentration inducer was removed by filtration under a sterile condition using a $0.22 \mu \mathrm{m}$ water filter, as shown in Table 1 and Table 2. Then, it was placed in a suspension culture at $28^{\circ} \mathrm{C}, 120 \mathrm{r} / \mathrm{min}$ for 28 days, and each concentration was repeated 3 times, and 3 controls were set at the same time.

\section{Different Inducer Orthogonal Test}

According to the results of single factor test, after the significance test of spss data processing system, the inducers with significant differences were selected for orthogonal test, and the yield of essential oil was used as the index to carry out the orthogonal test of $\mathrm{L}_{16}\left(4^{5}\right)$ (Tables 3-6), each set of experiments was repeated 3 times.

Extraction and Determination of Essential Oil from Suspension Cells of

\section{Ingepaniculatum}

The suspension cells were removed from the culture flask under sterile conditions every 7 days and dried at $55^{\circ} \mathrm{C}$. Accurately weigh $0.2000 \mathrm{~g}-0.6000 \mathrm{~g}$ of $C$. longepaniculatum suspension cells, add 4 times (1:4) of cyclohexane or petroleum ether for cold soak overnight, then treat in ultrasonic cleaner at $70^{\circ} \mathrm{C}$ for 30 $\mathrm{min}$, and finally centrifuge at $5000 \mathrm{r} / \mathrm{min}$ for $4 \mathrm{~min}$. The supernatant was taken and made up to $5 \mathrm{~mL}$ with cyclohexane. The liquid was extracted with a syringe, and the filter was filtered into a sample bottle to determine the content of the essential oil, which was analyzed by GC-MS. Chromatographic conditions: column temperature $60^{\circ} \mathrm{C}$; HP-5MS column, $30 \mathrm{~m} \times 0.250 \mathrm{~mm}$; injection volume is $1 \mu \mathrm{L}$; programmed temperature: from $60^{\circ} \mathrm{C}$ after the temperature increase rate of $10^{\circ} \mathrm{C} / \mathrm{min}$ to $190^{\circ} \mathrm{C}$ and maintained for $2 \mathrm{~min}$, Then, it was raised to $210^{\circ} \mathrm{C}$ for 2 min at a temperature increase rate of $5^{\circ} \mathrm{C} / \mathrm{min}$, and then increased to $220^{\circ} \mathrm{C}$ for 8 min at a temperature increase rate of $10^{\circ} \mathrm{C} / \mathrm{min}$, and then injected into a GC-MS to obtain a standard curve, that is, essential oil content response value was obtained. Further, the essential oil content was calculated [17] (1,8-eucalyptol: $Y=$ $73900 X-299200, \mathrm{R}^{2}=0.9993$ ). 
Table 3. Effects of different inorganic inducers on the accumulation of essential oil in suspension culture cells.

\begin{tabular}{|c|c|c|c|c|}
\hline \multirow{2}{*}{ Time (d) } & \multicolumn{4}{|c|}{ 1,8-eucalyptus oil (mg/L) } \\
\hline & $7 \mathrm{~d}$ & $14 \mathrm{~d}$ & $21 \mathrm{~d}$ & $28 \mathrm{~d}$ \\
\hline $\mathrm{CuSO}_{4}(0.010 \mathrm{mmol} / \mathrm{L})$ & 0.0370 & 0.0396 & 0.0423 & 0.0399 \\
\hline $\mathrm{CuSO}_{4}(0.020)$ & 0.0410 & $0.0530^{*}$ & 0.0492 & 0.0460 \\
\hline $\mathrm{CuSO}_{4}(0.030)$ & 0.0400 & 0.0456 & 0.0461 & 0.0428 \\
\hline $\mathrm{CuSO}_{4}(0.040)$ & 0.0397 & 0.04351 & 0.0432 & 0.0395 \\
\hline $\mathrm{FeSO}_{4}(0.020 \mathrm{mmol} / \mathrm{L})$ & 0.0351 & 0.0401 & 0.0389 & 0.0380 \\
\hline $\mathrm{FeSO}_{4}(0.035)$ & 0.0384 & 0.0425 & 0.0489 & 0.0465 \\
\hline $\mathrm{FeSO}_{4}(0.050)$ & 0.0435 & 0.0533 & $0.0635^{*}$ & 0.0619 \\
\hline $\mathrm{FeSO}_{4}(0.075)$ & 0.0385 & 0.0486 & 0.0598 & 0.0541 \\
\hline $\mathrm{Li}_{2} \mathrm{SO}_{4}(0.5 \mathrm{mg} / \mathrm{L})$ & 0.0489 & 0.0569 & 0.0652 & 0.0650 \\
\hline $\mathrm{Li}_{2} \mathrm{SO}_{4}(1.0)$ & 0.0590 & 0.0653 & $0.0792^{* *}$ & 0.0790 \\
\hline $\mathrm{Li}_{2} \mathrm{SO}_{4}(1.5)$ & 0.0543 & 0.0658 & 0.0732 & 0.0721 \\
\hline $\mathrm{Li}_{2} \mathrm{SO}_{4}(2.0)$ & 0.0511 & 0.0600 & 0.0632 & 0.0620 \\
\hline $\mathrm{MnSO}_{4}(1 \mathrm{mmol} / \mathrm{L})$ & 0.0452 & 0.0496 & 0.0495 & 0.0487 \\
\hline $\mathrm{MnSO}_{4}(3)$ & 0.0536 & 0.0557 & $0.0632^{\star}$ & 0.0624 \\
\hline $\mathrm{MnSO}_{4}(5)$ & 0.0480 & 0.0525 & 0.0590 & 0.0586 \\
\hline $\mathrm{MnSO}_{4}(7)$ & 0.0431 & 0.0543 & 0.0598 & 0.0591 \\
\hline $\mathrm{CaSO}_{4}(0.5 \mathrm{mg} / \mathrm{L})$ & 0.0650 & 0.0680 & 0.0692 & 0.0670 \\
\hline $\mathrm{CaSO}_{4}(1.0)$ & 0.0689 & 0.0742 & 0.0798 & 0.0765 \\
\hline $\mathrm{CaSO}_{4}(1.5)$ & 0.0732 & 0.0768 & $0.0824^{\star *}$ & 0.0804 \\
\hline $\mathrm{CaSO}_{4}(2.0)$ & 0.0651 & 0.0684 & 0.0675 & 0.0659 \\
\hline $\mathrm{H}_{2} \mathrm{O}_{2}(3 \mathrm{mmol} / \mathrm{L})$ & 0.0521 & 0.0556 & 0.0562 & 0.0552 \\
\hline $\mathrm{H}_{2} \mathrm{O}(6)$ & 0.0601 & 0.0621 & 0.0634 & 0.0620 \\
\hline $\mathrm{H}_{2} \mathrm{O}(9)$ & 0.0601 & 0.0642 & $0.0692^{\star \star}$ & 0.0675 \\
\hline $\mathrm{H}_{2} \mathrm{O}(12)$ & 0.0561 & 0.0614 & 0.0634 & 0.0624 \\
\hline Control & 0.0351 & 0.0467 & 0.0512 & 0.0436 \\
\hline
\end{tabular}

Note: ${ }^{*}$ There is a significant difference in inorganic inducers.

Table 4. Effect of different organic inducers on the accumulation of essential oil in suspension cells.

\begin{tabular}{ccccc}
\hline & \multicolumn{4}{c}{1,8 -eucalyptus $(\mathrm{mg} / \mathrm{L})$} \\
\cline { 2 - 4 } Time $(\mathrm{d})$ & $7 \mathrm{~d}$ & $14 \mathrm{~d}$ & $21 \mathrm{~d}$ & $28 \mathrm{~d}$ \\
\hline Tryptophan $(0.140 \mathrm{~g} / \mathrm{L})$ & 0.0442 & 0.0505 & 0.0563 & 0.0553 \\
Tryptophan $(0.144)$ & 0.0451 & 0.0513 & 0.0576 & 0.0566 \\
Tryptophan $(0.148)$ & 0.0482 & 0.0549 & $0.0597^{\star}$ & 0.0589 \\
Tryptophan $(0.152)$ & 0.0472 & 0.0542 & 0.0536 & 0.0531 \\
$\operatorname{SA}(5 \mathrm{mg} / \mathrm{L})$ & 0.0499 & 0.0596 & 0.0699 & 0.0676 \\
\hline
\end{tabular}




\section{Continued}

\begin{tabular}{cllll}
\hline SA (15) & 0.0513 & 0.0656 & $0.0700^{* *}$ & 0.0630 \\
SA (25) & 0.0495 & 0.0584 & 0.0675 & 0.0634 \\
SA (35) & 0.0503 & 0.0607 & 0.0653 & 0.0622 \\
Sodium benzoate (5 mg/L) & 0.0486 & 0.0546 & 0.0561 & 0.0551 \\
Sodium benzoate (10) & 0.0487 & 0.0593 & $0.0674^{*}$ & 0.0658 \\
Sodium benzoate (15) & 0.0488 & 0.0577 & 0.0649 & 0.0599 \\
Sodium benzoate (20) & 0.0469 & 0.0489 & 0.0485 & 0.0451 \\
Control & 0.0351 & 0.0467 & 0.0512 & 0.0436 \\
\hline
\end{tabular}

Note: ${ }^{\star}$ There is a significant difference in inorganic inducers.

Table 5. Orthogonal test of different inducers.

\begin{tabular}{|c|c|c|c|c|c|c|}
\hline \multirow{2}{*}{ Test number } & \multicolumn{5}{|c|}{ Factor Factor } & \multirow{2}{*}{$\begin{array}{c}\text { 1,8-eucalyptus } \\
(\mathrm{mg} / \mathrm{L})\end{array}$} \\
\hline & A & B & $\mathrm{C}$ & $\mathrm{D}$ & $\mathrm{E}$ & \\
\hline 1 & $1(0.5)$ & $1(3)$ & $1(5)$ & $1(0.5)$ & & 0.0988 \\
\hline 2 & $2(1)$ & $2(6)$ & 1 & $2(1.0)$ & & 0.1121 \\
\hline 3 & $3(1.5)$ & $3(9)$ & 1 & $3(1.5$ & & 0.1342 \\
\hline 4 & $4(2)$ & $4(12)$ & 1 & $4(2.0)$ & & 0.1656 \\
\hline 5 & 2 & 4 & $3(25)$ & 1 & & 0.1321 \\
\hline 6 & 4 & 3 & $2(15)$ & 1 & & 0.1768 \\
\hline 7 & 3 & 2 & $4(35)$ & 1 & & 0.1321 \\
\hline 8 & 1 & 4 & 4 & 3 & & 0.1154 \\
\hline 9 & 4 & 1 & 4 & 2 & & 0.1541 \\
\hline 10 & 1 & 3 & 3 & 2 & & 0.0879 \\
\hline 11 & 2 & 3 & 4 & 4 & & 0.1103 \\
\hline 12 & 2 & 1 & 2 & 3 & & 0.0854 \\
\hline 13 & 3 & 1 & 3 & 4 & & 0.1103 \\
\hline 14 & 3 & 4 & 2 & 2 & & 0.1384 \\
\hline 15 & 4 & 2 & 3 & 3 & & 0.1569 \\
\hline 16 & 1 & 2 & 2 & 4 & & 0.0843 \\
\hline $\mathrm{k} 1$ & 0.3864 & 0.4486 & 0.5107 & 0.5398 & & \\
\hline $\mathrm{k} 2$ & 0.4399 & 0.4854 & 0.4849 & 0.4925 & & \\
\hline $\mathrm{k} 3$ & 0.5150 & 0.5092 & 0.4872 & 0.4919 & & \\
\hline $\mathrm{k} 4$ & 0.6534 & 0.5515 & 0.5119 & 0.4705 & & \\
\hline $\mathrm{k} 1$ & 0.0966 & 0.1122 & 0.1278 & 0.1350 & & \\
\hline $\mathrm{k} 2$ & 0.1100 & 0.1214 & 0.1212 & 0.1231 & & \\
\hline $\mathrm{k} 3$ & 0.1288 & 0.1273 & 0.1218 & 0.1230 & & \\
\hline $\mathrm{k} 4$ & 0.1634 & 0.1379 & 0.1280 & 0.1176 & & \\
\hline $\mathrm{R}$ & 0.0668 & 0.0257 & 0.0068 & 0.0174 & & \\
\hline
\end{tabular}

Note: A: $\mathrm{CaSO}_{4}(\mathrm{mg} / \mathrm{L}) ; \mathrm{B}: \mathrm{H}_{2} \mathrm{O}_{2}(\mathrm{mmol} / \mathrm{L}) ; \mathrm{C}: \mathrm{SA}(\mathrm{mg} / \mathrm{L}) ; \mathrm{D}: \mathrm{Li}_{2} \mathrm{SO}_{4}(\mathrm{mg} / \mathrm{L})$. 
Table 6. Analysis of variance of essential oil accumulation in orthogonal experiment of different inducers.

\begin{tabular}{cccccc}
\hline Variance source sv & Square sum ss & Degree of freedom df & Mean square ms & F & P \\
\hline A & 0.010 & 3 & 0.003 & 36.990 & $0.007^{*}$ \\
B & 0.001 & 3 & 0.000 & 5.130 & 0.106 \\
C & 0.000 & 3 & $5.341 \mathrm{E}-005$ & 0.589 & 0.663 \\
D & 0.001 & 3 & 0.000 & 2.360 & 0.250 \\
Error & 0.000 & 4 & $9.072 \mathrm{E}-005$ & & \\
Total variation & 0.261 & 16 & & & \\
\hline
\end{tabular}

Note: ${ }^{*} \mathrm{p}<0.01$.

\section{Significance Test of Experimental Data}

The experimental data was entered into the SPSS data processing system table and statistical analysis of the single factor test was performed on a completely random design of the test statistics tab. Perform a significant test on the experimental data and create a line graph of the experimental results in an Excel spreadsheet.

\section{Results}

The Effect of Single Factor of Inorganic Inducer on the Yield of Essential Oil from Oil Cell Suspension Cells

B5 medium was prepared, and the essential oil production was measured on the 7th, 14th, 21st and 28th day of suspension cell culture. The effect of single factor of each inorganic inducer on the accumulation of essential oil in the suspension cells of $C$. longepaniculatum was examined. The results are shown in Table 3. The results shown in the table are the average of 3 trials.

Table 3 shows that the oily suspension cells treated with each inorganic inducer showed an increase in the yield of most of the essential oil in the range of $21 \mathrm{~d}$, and reached the maximum at $21 \mathrm{~d}$. When the culture time was greater than $21 \mathrm{~d}$, the essential oil content in the suspension cells gradually decreased; as the concentration of the inorganic inducer increased, the essential oil production increased first and then decreased, but the cells may be aging, and some cells reached the maximum in the second cycle. The overall trend of the increase was higher than that of the no-inducer group (CK). The effects of essential oil accumulation on the $C$. longepaniculatum cell suspension cells treated with inorganic inducers were basically consistent. Among them, at the 21st day, the induced concentrations of $\mathrm{CuSO}_{4}, \mathrm{FeSO}_{4}, \mathrm{Li}_{2} \mathrm{SO}_{4}, \mathrm{MnSO}_{4}, \mathrm{CaSO}_{4}, \mathrm{H}_{2} \mathrm{O}_{2}$ were 0.02 $\mathrm{mmol} / \mathrm{L}, 0.05 \mathrm{mmol} / \mathrm{L}, 1.0 \mathrm{~g} / \mathrm{L}, 3 \mathrm{mmol} / \mathrm{L}, 1.5 \mathrm{mg} / \mathrm{L}, 9 \mathrm{mmol} / \mathrm{L}$, respectively. The essential oil yield was the largest under the treatment of this inorganic inducer, $0.0530 \mathrm{mg} / \mathrm{L}, 0.0635 \mathrm{mg} / \mathrm{L}, 0.0792 \mathrm{mg} / \mathrm{L}, 0.0632 \mathrm{mg} / \mathrm{L}, 0.0824 \mathrm{mg} / \mathrm{L}, 0.0692$ $\mathrm{mmol} / \mathrm{L}$, respectively. The yield increased by $3.52 \%, 24.02 \%, 54.69 \%, 23.44 \%$, $60.94 \%, 35.16 \%$, respectively. According to the significance test, the induced concentrations of $\mathrm{CuSO}_{4}, \mathrm{FeSO}_{4}, \mathrm{Li}_{2} \mathrm{SO}_{4}, \mathrm{MnSO}_{4}, \mathrm{CaSO}_{4}$ and $\mathrm{H}_{2} \mathrm{O}_{2}$ were respec- 
tively $0.02 \mathrm{mmol} / \mathrm{L}, 0.05 \mathrm{mmol} / \mathrm{L}, 1.0 \mathrm{mg} / \mathrm{L}, 3 \mathrm{mmol} / \mathrm{L}, 1.5 \mathrm{mg} / \mathrm{L}, 9 \mathrm{mmol} / \mathrm{L}$ at 21 $\mathrm{d}$, there was a significant difference between the yield of 1,8-eucalyptus oil and other concentrations under the inducer at this time $(\mathrm{P}<0.05)$. According to the SPSS significance test, $\mathrm{CaSO}_{4}$ had the most significant difference compared with other inorganic inducers on the 21 st day.

Effects of Organic Inducer Single Factor on the Yield of Essential Oil from Suspension Cells

B5 medium was prepared, and the same concentration of organic inducer was added after sterilization and cooling. The essential oil production was measured on the 7th, 14th, 21st and 28th day of suspension culture, and the single factor of each organic inducer was detected. The results are shown in Table 4, the results shown in the table are the average of 3 trials.

Table 4 shows that the essential oil production increased in the range of $21 \mathrm{~d}$ when the cultured cells were treated with organic inducers, and reached the maximum at $21 \mathrm{~d}$. When the culture time was greater than $21 \mathrm{~d}$, the content of essential oil in suspended cells decreased gradually. With the increase of organic inducer concentration, the yield of essential oil increased first and then decreased. The yield was higher than that of the no-inducer group (CK). The effects of essential oil accumulation on the suspension cells of $C$. longepaniculatum treated by organic inducers were basically consistent. Among them, on the 21st day, when the concentrations of tryptophan, SA and sodium benzoate were $0.148 \mathrm{~g} / \mathrm{L}, 15 \mathrm{mg} / \mathrm{L}$ and $10 \mathrm{mg} / \mathrm{L}$, respectively, the essential oil yield was the highest under the treatment of organic inducer, which was 0.0597 $\mathrm{mg} / \mathrm{L}, 0.0700 \mathrm{mmol} / \mathrm{L}, 0.0674 \mathrm{mmol} / \mathrm{L}$, the yield increased by $16.60 \%, 36.72 \%$, $31.64 \%$ compared with CK; according to significant test analysis, on the 21 st, tryptophan, SA, sodium benzoate induced concentration of $0.148 \mathrm{~g} / \mathrm{L}, 15 \mathrm{mg} / \mathrm{L}$ and $10 \mathrm{mg} / \mathrm{L}$, the yield of 1,8-eucalyptus oil was significantly different from that of other concentrations under the inducer at this time $(\mathrm{P}<0.05)$.

\section{Different inducer orthogonal test}

Four factors including $\mathrm{CaSO}_{4}, \mathrm{H}_{2} \mathrm{O}_{2}, \mathrm{Li}_{2} \mathrm{SO}_{4}$ and SA were selected by orthogonal test, and $\mathrm{L}_{16}\left(4^{5}\right)$ was used as the index of essential oil production of orthogonal test (Table 5). The results of the variance analysis of the essential oil production in the inducer induction test are shown in Table 6. The variance analysis of essential oil production by orthogonal test of different inducers showed that the inducer for the significant difference in essential oil production was $\mathrm{CaSO}_{4}$, and the other three inducers did not reach a significant level for the essential oil production. Through the orthogonal test, the influence of the $\mathrm{R}$ value of the four factors in Table 5 on the essential oil yield is: $\mathrm{CaSO}_{4}>\mathrm{Li}_{2} \mathrm{SO}_{4}>$ $\mathrm{SA}>\mathrm{H}_{2} \mathrm{O}_{2}$.

The yields of essential oil and the $\mathrm{K}$ value of each group in different orthogonal test tables were analyzed. The optimal combination of 4 groups was selected, namely $\mathrm{A}_{4} \mathrm{~B}_{4} \mathrm{C}_{1} \mathrm{D}_{4}, \mathrm{~A}_{4} \mathrm{~B}_{4} \mathrm{C}_{4} \mathrm{D}_{4}, \mathrm{~A}_{4} \mathrm{~B}_{4} \mathrm{C}_{1} \mathrm{D}_{1}, \mathrm{~A}_{4} \mathrm{~B}_{4} \mathrm{C}_{4} \mathrm{D}_{1} 4$ groups conduct verification tests. The results showed that when $\mathrm{CaSO}_{4} 2.0 \mathrm{mg} / \mathrm{L}, \mathrm{H}_{2} \mathrm{O}_{2} 9 \mathrm{mmol} / \mathrm{L}, \mathrm{SA} 15$ $\mathrm{mg} / \mathrm{L}, \mathrm{Li}_{2} \mathrm{SO}_{4} 0.5 \mathrm{mg} / \mathrm{L}$ were added to the suspension medium, the yield was the 
largest. It was $0.1768 \mathrm{mg} / \mathrm{L}$, and compared with the yield of CK which have no inducer was increased by $245.31 \%$.

\section{Discussion}

Studies have found that the addition of inducers can alter the pathway of secondary metabolite synthesis; it can also promote or inhibit the activity of key rate-limiting enzymes in the bio-metabolite synthesis pathway [18]; this experiment shows that there are differences between different inducers against $C$. longepaniculatum suspension cells and the effects of essential oil production, indicating that different inducers can affect the accumulation of essential oil in suspension cells to varying degrees.

In the single factor experiment, the suspension cells were treated with inorganic inducers $\mathrm{CaSO}_{4}, \mathrm{H}_{2} \mathrm{O}_{2}, \mathrm{Li}_{2} \mathrm{SO}_{4}$, and the essential oil yield was compared with other inducers. There are significant difference $(\mathrm{P}<0.05)$, and $\mathrm{CaSO}_{4}$ was more significant than the other two, the yield was larger, reaching $0.0824 \mathrm{mg} / \mathrm{L}$, which was $60.94 \%$ higher than CK. This is related to calcium ion Activator-related, it activates certain secondary metabolic pathways to increase metabolite production; $\mathrm{H}_{2} \mathrm{O}_{2}$ regulates gene expression and signaling as a signaling molecule to regulate secondary metabolic pathways [19]. The yield of essential oil treated by $\mathrm{CuSO}_{4}, \mathrm{FeSO}_{4}$ and $\mathrm{MnSO}_{4}$ is higher than that of $\mathrm{CK}$, but the difference is not significant, which promotes the accumulation of essential oil, but it is not significant, and the specific reasons need to be further carried out and explored. In summary, the promotion of the inorganic inducer on the accumulation of essential oil in the suspension cells of C. longepaniculatum is $\mathrm{CaSO}_{4}>$ $\mathrm{Li}_{2} \mathrm{SO}_{4}>\mathrm{H}_{2} \mathrm{O}_{2}>\mathrm{FeSO}_{4}>\mathrm{MnSO}_{4}>\mathrm{CuSO}_{4}$.

Treatment of $C$. longepaniculatum suspension cells with organic inducer SA can significantly promote the yield of essential oil from $C$. longepaniculatum suspension cells, reaching $0.0700 \mathrm{mmol} / \mathrm{L}$, which is $36.72 \%$ higher than CK. It is found that SA acts as a signal molecule involved in signal transduction, activation and inhibition. The corresponding transcription factors affect the expression of genes and regulate the synthesis of secondary metabolites [20]. In summary, the promoting effect of organic inducers on the accumulation of essential oil in oil suspension cells was: SA > sodium benzoate > tryptophan. Therefore, based on the difference in the accumulation of essential oil, the dominant inducer can be found, thereby optimizing the way to induce the accumulation of essential oil in the suspension of cells.

In the orthogonal experiment, $\mathrm{CaSO}_{4}$ had significant differences in the yield of essential oil from the C. longepaniculatum cell suspension compared with $\mathrm{H}_{2} \mathrm{O}_{2}$, $\mathrm{Li}_{2} \mathrm{SO}_{4}$, SA. The three inducers had no yield for essential oil. To achieve the level of significance, the effect of promoting essential oil production in orthogonal test was: $\mathrm{CaSO}_{4}>\mathrm{Li}_{2} \mathrm{SO}_{4}>\mathrm{SA}>\mathrm{H}_{2} \mathrm{O}_{2}$. Orthogonal test showed that when the callus suspension cells were added $\mathrm{CaSO}_{4} 2.0 \mathrm{mg} / \mathrm{L}, \mathrm{H}_{2} \mathrm{O}_{2} 9.0 \mathrm{mmol} / \mathrm{L}, \mathrm{SA} 15$ $\mathrm{mg} / \mathrm{L}, \mathrm{Li}_{2} \mathrm{SO}_{4} 0.5 \mathrm{mg} / \mathrm{l}$. The yield of essential oil was the highest at $0.1768 \mathrm{mg} / \mathrm{L}$, 
which was $245.31 \%$ higher than that without inducer. This indicated that the orthogonal combination of different inducers had the best effect on the yield of essential oil in suspension cells and the inducers in several different pathways added simultaneously have synergistic effects [21].

In this experiment, the effects of nine inducers and their partial combinations on the accumulation of essential oil in the suspension cells of $C$. longepaniculatum were studied, which promoted the accumulation of essential oil to some extent, but also encountered some problems in the experiment: such as the freshness of the cells and the effect of the length of the suspension cell culture cycle on the accumulation of essential oil, which needs further study. In the process of suspension culture of callus in the future, we can also optimize the culture conditions of its growth stage and metabolite synthesis stage, which lays a foundation for artificial regulation and optimization of the accumulation of secondary metabolites in induced callus.

\section{Acknowledgements}

The first and corresponding author acknowledges that this work was supported by Key Lab of Aromatic Plant Resources Exploitation and Utilization in Sichuan Higher Education (grant no. 2015XLY002).

\section{Conflicts of Interest}

The authors declare no conflicts of interest regarding the publication of this paper.

\section{References}

[1] Xu, Y.X., Wen, M. and Cai, F.L. (2017) The Present Situation Analysis and Development Countermeasures of Camphor Oil Industry in Yibin County. Journal of Sichuan Forestry Science and Technology, 38, 69-71+109.

[2] Hu, W.J. and Jiang, X.M. (2017) Comparison of Essential Oil Components Fromroots of Cineol Type and Isonerolidol Type in Cinnamomum camphora (L.) Presl. Journal of Northwest A \& F University (Natural Science Edition), 45, 189-195.

[3] Wang, W.Y., Gu, L.L. and Wu, Z.M. (2007) Research Progress of 1,8-Cineole. Food and Drug, No. 2, 56-59.

[4] Cong, Y., Zhang, L., Zu, Y.G., et al. (2016) Anti-Inflammatory and Antioxidant Activities of Cinnamomum longepaniculatum Essential Oil. Bulletin of Botanical Research, 36, 949-954+960.

[5] Ao, G., Du, Y., Wei, Q., et al. (2015) Antioxidant Activity of Cinnamomum longepaniculatum Leaves Polysaccharide on Edible Oil. Journal: Food Research and Development, 36, 14-17.

[6] Huang, T., You, L., Du, Y., et al. (2014) Inhibiting Effects of by-Products from Cinnamomum longepaniculatum Oil on Pathogenic Bacteria Skin Infection. Journal of Sichuan Agricultural University, 32, 53-58.

[7] Zhao, L. (1994) The Kingdom of Cinnamomum longepaniculatum Is Sweet and Sweet in the Market. Business Manager, No. 9, 35-36. 
[8] Wu, Y. (2010) Induction and Regulation on Cinnamomum camphora Callus. Journal of Hubei University for Nationalities (Natural Science), 28, 216-218.

[9] Deepak, K.V., Subakarivin, J.J., Narayanan, G.S., Prakash, M., Murugan, S. and Anandan, R. (2019) Efficient Plant Regeneration and Histological Evaluations of Regenerants through Organogenesis and Somatic Embryogenesis in Spermacoce hispida L.-An Underutilized Medicinally Important Plant. Industrial Crops \& Products, 134, 292-302. https://doi.org/10.1016/j.indcrop.2019.03.067

[10] Li, J., Zhang, D., Que, Q., Chen, X. and Ouyang, K. (2019) Plant Regeneration and Agrobacterium-Mediated Transformation of the Miracle Tree Neolamar ckiacadamba. Industrial Crops \& Products, 130, 443-449. https://doi.org/10.1016/j.indcrop.2019.01.009

[11] Yan, K., Chen, F., Wei, Q., et al. (2017) Effects of Endophytic Fungi on Its Essential Oil Accumulation and Physiological-Biochemical Characteristic of Cinnamomum longepaniculatum. Biotechnology Bulletin, 33, 138-143.

[12] Wongkietkachorn, A., Surakunprapha, P., Luvira, V., Wongkietkachorn, N. and Wongkietkachorn, S. (2019) Remove Persistent Staining with a Callus Shaver. Plastic and Reconstructive Surgery-Global Open, 7, e2140.

[13] Wang, C., Tan, Y., Yang, S., et al. (2017) Effects of Different Inducers on Endophytic Fungi of Cinnamomum longepaniculatum. Journal of Anhui Agricultural Sciences, $45,14-17+45$.

[14] Vázquez-Hernández, M.C., Parola-Contreras, I., Montoya-Gómez, L.M., TorresPacheco, I., Schwarz, D. and Guevara-González, R.G. (2019) Eustressors: Chemical and Physical Stress Factors Used to Enhance Vegetables Production. Scientia Horticulturae, 250, 223-229. https://doi.org/10.1016/j.scienta.2019.02.053

[15] de Freitas, T.F.S., Stout, M.J. and Sant'Ana, J. (2019) Effects of Exogenous Methyl Jasmonate and Salicylic Acid on Rice Resistance to Oebalus pugnax. Pest Management Science, 75, 744-752. https://doi.org/10.1002/ps.5174

[16] Ren, N., Liu, J., Yang, D.L., et al. (2019) Effects of Precursors and Elicitors on Production of Ethyl Vincamine by Endophytic FungusCH1. Journal of Central South University (Science and Technology), 50, 279-285.

[17] Cheng, S.L., Yan, X.C., Lu, G.Y., et al. (2019) Determination of Benzene Content in Sanitary Scent by Headspace Capillary Gas Chromatography. Chinese Hygienic Insecticide, 25, 105-107.

[18] Chen, Y., Xie, Q., Tang, Y., et al. (2018) Advances in Synthetic Metabolic Pathways and Rate-limiting Enzymes of Plant Terpene. Molecular Plant Breeding, 16, 2371-2379.

[19] Xu, L. (2008) Screening and Pharmacological Study of Activator in Chinese Medicine Monomer Compounds. Northeast Normal University, Jilin.

[20] Wei, Z. (2014) Effects of Salicylic Acid, Calcium Ion and $\mathrm{H}_{2} \mathrm{O}_{2}$ on Pal Gene Expression in Suspension Cells of Salvia Miltiorrhiza. Northwest A \& F University, Yangling.

[21] Feng, W. (2016) Effects of Different Elicitors on Resveratrol Content and Antioxidant Enzyme Activities in Wine Grape Grapevine Seedlings. Ningxia University, Yinchuan. 